\title{
PREGLED SUVREMENIH MIGRACIJA KRIVOPUĆANA
}

\author{
Marijeta RAJKOVIĆ \\ Filozofski fakultet Sveučilišta u Zagrebu \\ Odsjek za etnologiju i kulturnu antropologiju \\ Ivana Lučića 3, 10000 Zagreb
}

\section{UVOD ${ }^{1}$}

$\mathrm{N}$ a području Krivoga Puta istraživala sam u više navrata tijekom 2003. i 2004. godine. Prilikom razgovora svi su nas kazivači pozivali da dođemo u Krivi Put 5. kolovoza jer tada je ondje nešto sasvim drugo. $^{2} \mathrm{Na}$ taj se dan održava proslava blagdana Majke Božje Snježne kojoj je posvećena krivoputska crkva. Zbog depopuliranosti kraja, prilikom spomenutih istraživanja, razgovori s kazivačima nerijetko su vođeni u Senju gdje danas živi većina Krivopućana. No, 5. kolovoza gotovo su svi došli u Krivi Put jer je to prigoda da se susretnu: To je najveći praznik za nas, tad se svi vide jednom na leto. ${ }^{3}$

Ovaj je prilog najvećim dijelom rezultat terenskoga istraživanja u Krivome Putu od 3. do 6. kolovoza 2004. godine. Proslavu blagdana istraživalo se kroz dva aspekta. Sveti i svjetovni dio istraživale su studentice etnologije Marija Kulišić i Ivana Vuković. ${ }^{4}$ Moja su istraživanja bila usmjerena na dva cilja. Prvi je bio istražiti migracije Krivopućana, a drugi saznati današnju povezanost migranata s lokalnom zajednicom. Migracije stanovništva spomenute u kazivanjima bile su tijekom 20. stoljeća, za razliku od podataka vezanih uz dolazak iseljenih Krivopućana na proslavu Majke Božje Snježne koji se ponajviše odnose na 2004. godinu. Koristila sam tehnike promatranja i intervjua. ${ }^{5}$ Osim podataka prikupljenih ovom prigodom, koristila sam građu s vlastitih ranijih istraživanja, kada sam osim migracijskih mobilnosti istraživala i tradicijsko gospodarstvo, ${ }^{6}$ te tijekom boravka na proslavi spomen-dana Majke Božje Snježne 2005. godine.

\subsection{POLAZIŠTA I CILJEVI}

Iako su migracijska kretanja kao jedan od oblika prostorne pokretljivosti (cirkulacija je drugi) prisutna od pretpovijesnog doba do danas, zanimanje razlicitih znanosti za te socijalne fenomene kao da u posljednje vrijeme raste. (...) Migracije se proučavaju već više od stoljeća, da bi se jačanjem svijesti o ljudskim pravima $i$ slobodama one sve više proučavale multidisciplinarno i iz različitih rakursa, od mikrosocijalnih do makrosocijalnih (...) Hrvatska je izrazito migracijska zemlja, obilježena velikim unutrašnjim migracijama nakon Drugoga svjetskog rata (selo-grad) i mnogobrojnim iseljeništvom. (Babić i Mesić 2003:119)

Rad je u neznatno izmijenjenoj varijanti objavljen u Senjskom zborniku 31 iz 2004. godine.

Petar Tomljanović Čona, Podbilo.

3 Stipe Prpić Stipina, Gorica. Moram spomenuti da sam se i ja osjećala kao povratnik, poznavala sam većinu prisutnih, svi su nas pozdravljali.

4 Vidi članak istih autorica pod nazivom: 'Majka Božja Snježna u pučkoj pobožnosti na području Krivoga Puta', Senjski zbornik 31 .

5 Intervjuiranje je provođeno pojedinačno i grupno, a koristila sam polustrukturirani oblik intervjua.

6 Istraživala sam tradicijsku zemljoradnju, stočarstvo, pčelarstvo, sjenokošu i lov. Dio građe korišten je u prilogu o tradicijskom gospodarstvu u nastavku ove monografije.

7 Rezultati istraživanja bit će podrobnije predstavljeni u mojoj doktorskoj disertaciji. 
U radu sam nastojala prikazati koji su to faktori u domicilnom, a koji u migratornom okruženju uzrokovali migracije Krivopućana tijekom 20. stoljeća. Razmatraju se oblici vanjskih (transkontinentalni, u zapadnu Europu, susjedne zemlje) i unutrašnjih migracija (ponajviše u Slavoniju i bliža urbana središta). Nastoji se saznati jesu li migracije bile privremene, trajne, sezonske, lutajuće, lančane... Također se promatra današnja povezanost migranata, kao i njihovih potomaka, s lokalnom zajednicom. Prikazuje se povratak u lokalnu zajednicu, kako trajni, tako i privremeni, te dolazak na proslavu blagdana Majke Božje Snježne.

Prema mojim saznanjima, migracijama se Krivopućana nitko dosad nije sustavno bavio. Pronašla sam samo dva rada koji sadrže podatke o migracijama s ovoga područja. Tako primjerice, Milan Pavelić u radu o Partizanskom odredu Alan, navodi: Čitav kraj je jako brdovit, većinom golet s malo kraških udolja koje su stanovnici krčili, pa čak pourh Velebita iskorištavali u gajenju poljoprivrednih kultura... sagradivši skromne nastambe kako bi obitelji osigurali krov nad glavom, a sebi povremeno svratiste preko zime, jer je sve sposobno ljudstvo, moralo odlaziti u svijet tražeći rada i kruha kojeg kod kuće nije bilo...škrta kraška zemlja nije mogla osigurati ni najminimalnije životne uvjete, što je prisiljavalo mnoge ljude da preko ljetne sezone odlaze za radom u druge krajeve. (1979:211). Etnologinja Milana Černelić, u radu o Dvije zadružne obitelji na području Krivoga Puta piše o životu ukućana, te između ostaloga daje primjer lutajućih migracija muških članova jedne zadružne obitelji: Mile je dosta putovao za zaradom. ...od 1924. do 1925. godine, tražeći posla putovao je po Srbiji, Crnoj Gori, i drugdje po Kraljevini Jugoslaviji.(...) Stipe je kao zidar stalno putovao po Jugoslaviji, a kući je dolazio kao gost na mjesec dana. (...) Mirko je takoder već sa 12 godina krenuo trbuhom za kruhom. Najprije je bio u Našicama, gdje je kuhao za brigadu 6 mjeseci. Ponovno je krenuo sa 18 godina najprije po Srbiji kao naučnik kod zidara 1-2 godine, zatim po Crnoj Gori dvije godine i po Sloveniji 4-5 godina (...) Povremeno bi s putovanja dolazio na mjesec dva. 1937. došao je iz Slovenije $i$,stavio si žrvanj oko vrata" (oženio se). Ponovno je otišao u Sloveniju, zatim u Njemačku (...) Vratio se kući 1944. i nakon toga je ponovno zbog posla putovao po Srbiji i Bosni (...) Njegov brat Joso počeo je putovati u potrazi za poslom sa 16 godina. Bio je u Srbiji i Njemačkoj. (2000:200-201) Autorica ukazuje kako su migracije muških članova zadruge utjecale na organizaciju zadružnoga života i podjelu poslova unutar obitelji, posebice na promjenu ženine uloge.

Koristila sam radove o migracijama s područja Republike Hrvatske. Knjiga Većeslava Holjevca iz 1969. godine Hrvati izvan domovine pomogla mi je shvatiti migracije Krivopućana u kontekstu migracijskih kretanja s područja Republike Hrvatske. Rad fra Ilije Živkovića (svećenika), Željke Šporer i Duška Sekulića (sociologa) Asimilacija i identitet iz 1995. godine, poslužio mi je kao teorijska okosnica. U starijoj literaturi, posebice sociološkoj i demografskoj, možemo saznati da je upravo Ličko-senjska županija, u kojoj se nalazi Krivi Put, županija s najvećom stopom depopulacije od početka 1970.-ih godina. Opadanje broja stanovnika, kao rezultat radne migracije, istodobno je posljedica i uzrok zaostajanja u regionalnom razvoju. Kako se u pravilu iseljava mlade stanovništvo (...) to zbog slabljenja radnog potencijala periferije uzrokuje njezino još veće zaostajanje u regionalnom razvoju. (Babić i Mesić 2003:119). Osim navedenoga, razlog bavljenja migracijama Krivopućana smatram bitnim stoga što su migracije seoskog stanovništva, posebice poljoprivrednog, značajan element transformacije tradicionalne seoske socijalne strukture, što utječe na kulturni inventar iste zajednice (Štambuk 1981:125-130).

\section{POTISNI I PRIVLAČNI FAKTORI ISELJAVANJA}

$\mathrm{P}$ rimarne gospodarske grane na području Krivoga Puta bile su stočarstvo i zemljoradnja, a pojedinci su se bavili lovom na divlje životinje, ponajviše bez vatrenoga oružja, te pčelarstvom. Obitelji su imale volove, krave, konje, ovce, magarce, mule, svinje i perad. Posjedovale su nekoliko jutara zemlje, najviše oranice i livade, dok se stoka uglavnom napasala na zajedničkim pašnjacima na državnoj zemlji. ${ }^{8}$ Od poljoprivrednih su kultura najučestalije žitarice bile ječam i zob te povrtlarske kulture: krumpir, kupus, ma-

\footnotetext{
Više o tradicijskom gospodarstvu vidi u prilogu M. Rajković u nastavku Monografije.
} 
hunarke, mrkva i salata. ${ }^{9}$ Međutim, ove gospodarske djelatnosti nisu bile dovoljne za život, pa su muškarci nalazili dodatne izvore prihoda, što se zrcali u kazivanju Milana Tomljanovića Periše iz Zamalića: Mi smo bili kočijaši, neki kirijaši. ${ }^{10}$ Neki su išli radit na prugu u Srbiju, najviše u šumi, čak su neki i u Rumunjskoj tesali gradu, jer od poljoprivrede se nije moglo živjet. Onda bi obično ujesen uprtli torbu hrane, kolko možeš ponjet i po svijetu, u Crnu Goru, Srbiju onda se preko zime vrati nazad, pa u prolice opet. One sve pruge oko Čačka pa do Prištine, pa u Bosni, to je još moj pokojni djed od majke radia. Ćáa je i poginia na Palama. On je bia ka miner, mina zatajila on išso tamo i poginia. Onda je tamo i osta, onda majka poslje htjela ić tražit grob u Sarajevo, al' ju odgovorili jer 'ko zna gdje je zakopan. Tako da su ljudi najviše išli pčelarilit (smijeh), išli radit po svijetu.

Nakon Drugoga svjetskog rata, 1947. godine, napravljena je pilana, udaljena devet kilometara od Alana. ${ }^{11}$ Ondje je radilo stotinjak radnika iz Krivoga Puta i okolnih naselja, primjerice, iz Vratnika, Stolca, Krmpota, Crnoga Kala, Kosinja. Stanovnici iz bližih mjesta odlazili su kući svaku večer, dok su radnicima iz udaljenijih mjesta bile napravljene spavaonice i kuhinja. Poneki su ondje doselili s obiteljima i napravili privremene kuće. Danas na tome području nitko ne živi. Osim pilane, poslije Drugoga svjetskog rata osnovana je i zadruga. No, već šezdesetih godina 20. stoljeća, prema kazivanju Ivana Tomljanovića Čone iz Podbila: Bila je teorija svi u grad, onda su naši bižali. A nema di nas nema, ne postoji.

Kazivači navode da je na području općine Krivoga Puta "nekada" stanovalo preko 5 000, a čak do 6000 stanovnika. Petar Tomljanović Šimaica iz Podbila kazao je: nema ti tu nikoga danas ni 150 ljudi, sve ti se to raselilo moj sinko. Eto, dođu za Gospu.

Zbog lakšeg praćenja, sljedeća će nam tablica poslužiti da dobijemo potpuniju sliku o broju stanovnika Krivoga Puta od kraja 19. stoljeća do posljednjeg popisa stanovnika 2001. godine. ${ }^{12}$

\begin{tabular}{|l|c|c|c|c|c|c|c|c|c|c|}
\hline & 1890. & 1890. & 1910. & 1921. & 1931. & 1948. & 1953. & 1961. & 1971. & 2001. \\
\hline Alan & 477 & 396 & 451 & 391 & 370 & 282 & 321 & 260 & 91 & 11 \\
\hline Podbilo & 415 & 437 & 573 & 492 & 398 & 378 & 375 & 310 & 181 & 46 \\
\hline Krivi Put & 543 & 469 & 593 & 495 & 526 & 372 & 388 & 340 & 211 & 58 \\
\hline Mrzli Dol & 414 & 416 & 468 & 366 & 354 & 349 & 308 & 215 & 110 & 27 \\
\hline $\begin{array}{l}\text { Veljun } \\
\text { Primorski }\end{array}$ & 492 & 509 & 573 & 625 & 611 & 599 & 480 & 403 & 307 & 91 \\
\hline Ukupno & 2341 & 2227 & 2658 & 2369 & 2259 & 1980 & 1872 & 1528 & 900 & 233 \\
\hline
\end{tabular}

Iz tablice je vidljivo da je broj stanovnika od 1910. godine opadao. Između 1910. i 1921. godine Krivi Put izgubio je 289 stanovnika, od 1921. do 1931. godine 110 stanovnika, a od 1931. do 1948. godine 279 stanovnika. Nakon Drugoga svjetskog rata, od 1948. do 1953. godine, najmanji je pad broja stanovnika (108), da bi se nakon toga u idućih deset godina pad znatno povećao na 344 stanovnika. U razdoblju od 1971. do 2001. godine broj stanovnika smanjio se za 628. Prema posljednjem popisu stanovništva, dakle 2001. godine, u općini Krivi Put živi 233 stanovnika.

${ }_{9} \quad$ Za detaljniji uvid u prehranu vidi rad J. Jurković, te rad iste autorice 'Tradicijska prehrana kao prilog poznavanja primorsko-bunjevačkog identiteta', Senjski zbornik 31.

10 Za detaljniji uvid o kirijanju vidi rad D. Birt u nastavku Monografije, te rad iste autorice 'Transport i opskrba vodom na području Krivoga Puta', Senjski zbornik 31.

11 Prema mnogim kazivanjima pilana je trebala biti na mjestu današnjeg nogometnog igrališta u Podbilu, ali je zbog političkih razloga smještena u šumu iza Alanu. Naime, na tome je mjestu bila partizanska vojska.

12 Podaci o broju stanovnika do 1971. godine preuzeti su od M. Korenčić, 1979, 603-605. Za 2001. godinu iz Državnog zavoda za statistiku, http://www.dzs.hr/Hrv/Popis\%202001/popis/popis. Detaljnije o demografskim prilikama od 1857. do 1971. godine vidi u poglavlju kod B. Ljubović u ovoj monografiji. 
Zanimalo me koji su faktori u domicilnom, a koji u migratornom okruženju uzrokovali i omogućavali migraciju Krivopućana. Naime, migracija je uvijek reakcija na cijeli niz ekonomskih, socijalnih i političkih poticaja izvana na okolinu i pojedinca u njoj. Ti poticaji imaju zapravo oblik privlačnosti neke lokacije za pojedinca sa stanovitim vrijednosnim sustavom. Ako osoba ili cijele skupine zbog nekih promjena u vlastitoj okolini postanu nezadovoljni ... povećava se njihova spremnost da zamijene taj prostor onim koji je privlačniji (Lewis prema Živković et. al. 1995:11). Čimbenici koji guraju (push) prema migraciji u novi prostor jesu oni koji izazivaju nezadovoljstvo u vlastitoj okolini. Privlačni faktori (pull) su oni koji nedostaju domicilnom okruženju, a postoje u nekom drugom prostoru i djeluju privlačno. (Ibid. 11) Migracija je tako uzrokovana različitim snagama (odbojnosti i privlačnosti) koje djeluju na pojedince i skupine da napuste jedan prostor i budu privučeni u drugi.

Prema kazivanjima svih kazivača, ekonomski su faktori bili najveći uzroci masovnijih iseljavanja iz ovih prostora. Stoga su u prvoj polovici 20. stoljeća migranti s ovoga područja uglavnom bili mlađi muškarci. S obzirom da je migracija selektivan proces, u kojem u većoj mjeri sudjeluje mlade, radno i biološki najaktivnije stanovništvo, te u većoj mjeri muškarci, to se vanjska migracija može tretirati kao negativna komponenta kvalitativnih demografskih promjena u Republici. (Mikačić 1990:119) Zabilježila sam tek nekoliko slučajeva kada su djevojke pobjegle za momcima, no ove se migracije ne može ubrojiti u gospodarske. Ivan Tomljanović Rokin ističe kako je njegova sestra 1953. godine pobjegla za momkom, najprije u Italiju nakon čega su zajedno otišli u Francusku gdje i danas žive. Djevojka iz Matića otišla je kod brata u Njemačku 1963., udala se za momka iz Krivoga Puta i ostali su ondje živjeti, a brat je remigrirao u Kanadu.

Tek su pojedinačni kazivači spominjali političke razloge za odlazak. Naime, tijekom Drugoga svjetskog rata na području Alana bila je smještena partizanska vojska, a na području Mrzloga Dola je zaselak Pavelići, gdje su prema tumačenju kazivača živjeli preci Ante Pavelića prije no što su odselili u Bradinu u Hercegovini. Ante Pavelić bio je ustaški poglavnik u Nezavisnoj Državi Hrvatskoj. Stanovnici iz okolnih sela, prema kazivanjima, uglavnom nisu odlazili u partizansku vojsku, pa su stoga nakon Drugoga svjetskog rata bižali trbuhom za kruhom. ${ }^{13}$ Osim ekonomskih i političkih razloga, Zlatko Tomljanović Pešo iz Krivoga Puta naveo je vremenske prilike kao važne potisne faktore iseljavanja. $\mathrm{Na}$ ovom su planinskom području zimski uvjeti teški, snijeg padne prije početka studenoga i ne topi se do travnja, ponekad i svibnja, faktički si cijelu zimu odsječen od svijeta.

Luka Krmpotić Brnde iz Veljuna je kao razlog svoje prve migracije četrdesetih godina 20. stoljeća naveo želju za avanturom u nepoznato. Njegov je otac proizvodio i prodavao vapno, pa nije bilo potrebe za odlaskom na rad. Kao mladić od dvadesetak godina dogovorio se s nekoliko prijatelja, uzeo alat za rad u šumi i jedne su noći pobjegli od kuće. Prilikom odlaska nisu imali definirano odredište. Najprije su sjekli šumu u Sloveniji, zatim u Francuskoj. Avantura je trajala nekoliko mjeseci nakon čega su se vratili kući u novim baršunastim odijelima kakve nitko na području Krivoga Puta nije imao. Takva odijela i priče o „dalekom svijetu“ donijeli su im popularnost među djevojkama na „prelima“. Nakon prve migracije uslijedile su daljnje koje su s prekidima trajale više od desetak godina. Dakle, glavni su razlozi raseljavanja Krivopućana bili: ekonomska stagnacija poljoprivrede, urbanizacija, nepostojanje infrastrukture i komunikacije s bližim urbanim centrima.

\section{KRONOLOŠKI PREGLED MIGRACIJA KRIVOPUĆANA}

$\mathrm{P}$ odaci o migracijama s kraja 19. i početka 20. stoljeća dobiveni su uglavnom iz usmenih priča, koje se prepričavaju u lokalnoj zajednici, ili od potomaka samih migranata. Tako je muškarac iz Šolića, koji danas živi u Senju, rekao: Navodno je did otišao u Ameriku i više se nije ni vratio, onda se baka preudala u Primorje. Počela nanovo živjet život, imala još jednog sina i dvi čeri. U ovom su razdoblju prevladavali

13 Ivan Tomljanović Čona, Mara Tomljanović Isanova, Veljun; Petar Tomljanović Šimaica. 
aktivni migranti, dakle osobe koje su same istraživale moguća odredišta za odlazak na rad. ${ }^{14}$ Pritom često prilikom polaska migrant nije imao točno definirano odredište, kazala je Ivanka Atalić Garina iz Alana: Dvadesetih godina 20. stoljeća Alanari su išli po svijetu o radnjama, kad se radila pruga, zgrade, cesta, gdje nadi posla tu ostani. Put iz domovine u tudi svijet mnogima je obećavao sreću i rješenje teške životne situacije u kojoj su se nalazili. Odlazilo se u "obećanu zemlju" o kojoj se nije znalo ništa. (Holjevac 1967:23) Razdoblje intenzivnijeg i masovnijeg iseljavanja počinje oko godine 1860. i doseže vrhunac 1900-1910. (Holjevac 1967: 25, 29) Razlozi transkontinentalnih iseljavanja u SAD, Kanadu i Australiju početkom stoljeća bila su društveno gospodarska zbivanja (...) na jednoj, a uspostava čestih parobrodskih linija, proširena mreža agencija $i$ kredit za odlazak preko oceana, na drugoj strani. (Ibid. 25, 29)

Privremene transkontinentalne migracije ponekad su rezultirale remigracijom. ${ }^{15}$ Tako je Ivan Butković Gara iz Alana naveo kako su u vrijeme prije Drugog svjetskog rata Bunjevci počeli otvarati dućane i to oni koji su prethodno radili u Americi. Po povratku bi ostavljali svoje rodne kuć u zaledu Senja i kupovali nove u samom gradu Senju te na tom mjestu otvarali trgovine. Na taj način su doseljeni Bunjevci sebi osiguravali egzistenciju u gradu Senju. ${ }^{16}$ Navedeni primjer također potvrđuje stupnjevitu migraciju. Stupnjevita migracija znači preseljenje ljudi u više "koraka"; najprije se odlazi, primjerice iz manjeg mjesta u veće, iz jedne zemlje u drugu. (Heršak 1998:264). U ovom je slučaju odlazak u transkontinentalno područje bio privremen, što je rezultiralo trajnim preseljenjem u bliže urbano središte.

Dok su jedni početkom 20. stoljeća odlazili u prekomorske zemlje, drugi u zemlje zapadne Europe, treći su odlazili u ostale dijelove Hrvatske ili na istok. Najmasovnije su seobe bile u Slavoniju. ${ }^{17}$ Prema mnogim kazivanjima, odlazili su najviše drvosječe, odnosno šumski radnici, tražeći sezonski posao. Zlatko Tomljanović Pešo rekao je da takav odlazak nazivao odlaskom na "rajs”. Kada bi nakon ljeta i jeseni završila radna sezona, zaradilo bi se nešto novca te se vraćalo kući gdje bi provodili zimu. Josip Prpić Paljak iz Krivoga Puta, istaknuo je kako su stanovnici ovog područja imali mnogo djece, svake zime napravi jedno, jer nije bilo struje pa nisu imali sta delat nego dicu.

Do godine 1930. najveći broj iseljenika odlazi i dalje u prekomorske zemlje, dok se u razdoblju od 1930. do 1938. povećava interes za migraciju u evropske zemlje. (Holjevac 1967:39,22). Razlog je tome uplitanje državne politike, odnosno uvođenje sustava državnih kvota prilikom imigracije u SAD, tako da je između Prvoga i Drugoga svjetskog rata, kada je SAD praktično onemogućio useljavanje, velik broj Hrvata krenuo u zemlje zapadne Europe. U Europi nakon Drugoga svjetskog rata počinje konjunkturno razdoblje u gospodarstvu, što će je pretvoriti u imigracijsko odredište. Dok je noči prvog svjetskog rata od zapadnoevropskih zemalja najprivlačnija bila Njemačka, kasnije su naši ljudi krenuli u Belgiju, Francusku ... naročito kada je Francuska primila velik broj poljoprivrednih i šumskih radnika. Najveći dio bio je iz Gorskog kotara i Like, odakle su se iseljavali šumski radnici. (Ibid. 22) U tom razdoblju malo tko da nije išo van s krivoputskoga područja, kazali su svi moji sugovornici. U okviru „gastarbajterskog " ${ }^{18}$ modela međunarodnih migracija hrvatski su građani bili znatno zastupljeni, pogotovo u ondašnjoj SR Njemačkoj. Savezna Republika Njemačka i Austrija privukle su oko pola milijuna jugoslavenskih radnika koje je slijedio nepoznat broj članova obitelji. (Fassman et al. 1995:69) Odlaska preko granice je bilo i prije otvaranja granice socijalističke Jugoslavije, pa je tako već 1962. godine Zakonom o amnestiji bivša Jugoslavija legalizirala poslijeratne migrante

14 Aktivni migrant, od. engl. active migrant, dosl. znači "djelatan migrant". Aktivnim migrantom smatra se osoba koja sama istražuje moguća odredišta za migraciju (Heršak 1998:4).

15 Remigracija može biti svaka ponovna migracija, nakon prve u neku treću zemlju, međutim, naziv se ponekad koristi u užem smislu za povratništvo (Heršak 1998:232).

16 Vidi u: Rubić 2004.

17 Više vidi u prilogu M. Rajković i J. Jurković u ovoj monografiji.

18 Gastarbajter: izraz za vrstu migranata; od njem. Gast "gost" + Arbeiter "radnik", gostujući radnik (Heršak 1998:69). 
izvan svojih državnih granica. Situacija s "gastarbajterima“ se mijenja nakon tzv. naftne krize 1973./74. kada se pooštravaju mogući ulasci u zapadnoevropske zemlje, što će znatno oslabiti taj put migracija u Evropi. (Babić i Mesić 2003:120) Nakon toga je nastupila reemigracija u Jugoslaviju. (Malčić prema Fassman et al., 1995:69)

Krajem šezdesetih godina 20. stoljeća za odlazak u inozemstvo trebalo je imati jamstvo da će vas tamo netko primiti, radnu dozvolu i siguran posao, objasnio je Stipe Prpić Stipina iz Gorice prema vlastitom iskustvu: Ako su vam poslali garantno pismo onda ste mogli, moja sestra je bila udata u Švicarskoj onda mi je poslala garanciju za Švicarsku, to je bila sezonska viza. Onda je bilo posla u Evropi za radit, ovisi kako je 'ko dela $i$ 'ko je šta zna radit. To je bia lip život, ja sam onda ima 23 godine, moga sam otić na misec. Prvo sam bia u Švicarskoj par mjeseci, radia ka konobar, onda sam otiša u Njemačku. A svašta sam radia kak se snađeš. Onda sam otiša i u Engleskoj sam bio kratko da, i u Francuskoj, svašta eto. Vraća sam se 2, 3 puta godišnje. Kad sam se vratia oženia se lipo i dica došla. Nakon ženidbe napravio je kuću u Senju i više nije odlazio na privremene radove, kako je kroz smijeh kazao: Ma vrag bi bia sam gore, nisam više iša, treba imat nekog kraj sebe da te grije.

Krivopućani su pojedinačno selili u Koprivnicu, Podgorje, ${ }^{19}$ Požegu, Cabunu, ${ }^{20}$ Sisak, Varaždin. Osim u zapadnu Europu, česte su privremene migracije bile na istok, ponajviše u Srbiju, Vojvodinu i Crnu Goru, odnosno sve krajeve bogate šumom jer taj su posao migranti najbolje znali raditi, budući da su to i na području Krivoga Puta najviše radili. ${ }^{21}$ Suprotno tome, migranti koji su odlazili u zapadnu Europu najviše su radili građevinske i ugostiteljske poslove, kao kuhari i konobari.

Načini odlaska bili su uglavnom individualni. Osim legalnih migracija, poslije Drugoga svjetskog rata bilo je i nekoliko ilegalnih. Pojedinci su „bježali“ preko granice ako nisu imali nekoga da im pošalje jamstvene dokumente. ${ }^{22}$

Pojedine su privremene migracije postale višegodišnje. Duljina privremenih migracija ovisila je o pojedinome migrantu. Tako je primjerice, Petar Tomljanović Šimaica otišao živjeti u Sarajevo sa 14 godina i vratio se u Krivi Put nakon petnaest godina. Od tada stalno živi u Panjićima. Ivanka Atalić Garina, rođena na Alanu, sa 19 je godina otišla živjeti u Senj, nakon toga se udala i otišla s mužem u Slavoniju, gdje su živjeli četiri godine, da bi se onda preselili u Zagreb, gdje su bili pet godina. Potom su se vratili u Senj. Ovakvih priča zaista ima mnogo. Odlasci na privremene radove ni danas nisu prestali. Naime, razgovarala sam sa starijom ženom, rođenom u Panjićima, koja je radni vijek provela u Senju, a danas čuva djecu u Njemačkoj, jer, kako navodi, ne može živjeti od male mirovine. Prekinula je svoj privremeni rad i došla u Krivi Put na proslavu Majke Božje Snježne 2004. godine.

Osim navedenih migracija, na ovome je prostoru stanovništvo iz primorskih sela u proljeće selilo na veće nadmorske visine. Sela na jednakim nadmorskim visinama mogla su imati privremene i stalne stanovnike, te kombinacije istih. Osnovna škola, u koju su išla djeca iz širega područja, bila je u Vrataruši, groblje i crkva su u Krivome Putu, odnosno Podbilu. Razlozi seljenja Primoraca bili su ispaše blaga i obrađivanje zemlje; ondje bi kosili travu, sijali žitarice i sadili povrće. U jesen bi sve selili u Primorje gdje bi provodili vrijeme do proljeća. ${ }^{23}$ Takve seobe postajale su sve rjeđe od šezdesetih godina 20. stoljeća, a prestale su nakon sedamdesetih godina.

Nakon sedamdesetih godina, dakle nakon završetka velikih migracija u Senj i okolna urbana središta (Rijeku, Crikvenicu, Novi Vinodoloski), područje Krivoga Puta postalo je gotovo prazno. Treba spomenuti da u većini zaselaka danas živi tek nekolicina stanovnika, posebice zimi. U proljeće, međutim, mnogi

19 Prpić Rudolf Švorac, Podbilo.

20 Branko Tomljanović Ropeta, Krivi Put.

21 Špalj Anton Franetov, Marija Tomljanović Čonina, Petar Tomljanović Šimaica.

22 Ivan Tomljanović Rokin, Vrataruša.

23 Više o selidbama i suživotu na ljetnim stanovima vidi u M. Rajković u nastavku Monografije. 
Krivopućani, posebice oni u mirovini, sele u Krivi Put gdje provode vrijeme do jeseni odnosno prvog snijega. Vikendom ih posjećuju djeca i unuci. Nerijetki napominju da posade povrće, primjerice krumpir, salatu, mrkvu, mahune jer, kako kažu, ovdje sve uspijeva, samo treba zalijevati. Njihovi ljetni boravci ondje ujedno su razlog što mnogi danas obnavljaju stare kuće ili grade vikendice. Miro Prpić Ropeta je kazao: Dođu ljudi, vikendom, neko sadi baštu, krumpir budu tu liti, obnavljaju kuće, to drži uglavnom generacija koja sada ima 45-50 godina. Ovi koji imaju 20 njih to ne zanima. Kad budu 40 valjda će im proradit neki osjećaj. Danas žive u Senju, dolaze ovdje kako tko, uglavnom smo svi gosti. Ljudi koji su dalje odselili dolaze oni koji imaju vikendice, neki žive Senj, Crikvenica, neki imaju tu još rodbinu.

To je područje pogodno za pčelarstvo, stoga nekolicina pčelara porijeklom iz Krivoga Puta, Crikvenice ili Senja, kao i brojnih primorskih mjesta, ljeti seli onamo. Razlog je ispaša pčela na kadulju od svibnja do rujna. ${ }^{24}$

\subsection{KRIVOPUĆANI U SENJU}

$\mathrm{N}$

ajveći valovi iseljavanja iz Krivoga Puta bili su tijekom šezdesetih godina 20. stoljeća. Navedeno potvrđuju i podaci iz literature za područja ostalih dijelova Hrvatske: Kao točka preokreta uzima se reforma 1965. godine. Naime, u tom razdoblju "ekstenzivni" razvoj biva zamijenjen strategijom "intenzivnog" razvoja. Ekstenzivni razvoj obilježava razdoblje industrijalizacije nakon rata po sovjetskom uzoru. Osnovna značajka takvog modela se zasniva na masovnom transferu radne snage iz sela u grad, tj. iz poljoprivrede $u$ industriju. (Živković et al., 1995:14). Mjera gospodarske politike prema selu i poljoprivredi djelovala je destimulirajuće na razvoj poljoprivrede i ostanak na selu. Socijalna nesigurnost kao i podređen položaj seljaka, prometna izoliranost, nedostatak agrarne infrastrukture, kulturnih sadržaja, te slab razvoj društvenih djelatnosti temeljni su potisni činitelji deagrarizacije i deruralizacije. ${ }^{25}$ Kazivač Ivan Tomljanović Rokin iz Vrataruše također smatra da su političke elite tako htjele: Taki je bio sistem da je sve ljude trebalo selit odavle, nisu dali struju, vodu, ništa. Pilana je zatvorena 1966. godine, struja je uvedena u Krivi Put 1969. godine, u Vratarušu tek 1982. godine, a cesta je asfaltirana 1973. godine. Primjer iz vlastita života navela je Miroslava Filipaš Cotina: Dok sam ja bila curica nismo imali ništa, kad nemaš struju nemaš ništa, znaš kad smo po noći išli s onim lanternama, to je bila teška mladost, nije ko vaša danas.

Većina je Krivopućana u navedenom razdoblju odselila u Senj, u gradsku četvrt Mundaričevac. ${ }^{26}$ Razlog tome navodi Zlatko Tomljanović Pešo: Pomodarstvo, jedan je napravio kuću u Senju pa drugi i treći bitno da je krenulo, jer oni nisu dobivali stanove već su gradili kuće, 80 \% Krivopućana živi u Senju. U navedenoj četvrti živi od 1962. godine bračni par Prpić, Milan i Nada Brkac. Razlog preseljenja iz Šušnja objasnili su: To je po našem običaju ovca ovci leti, tako svak svome. Voliš susjeda imat svog, recimo jedino je Pepo Ličanin kod nas. I ima vamo još jedan Hercegovac, ostalo su sve Krivopućani. Osim radnih migranata u obližnja urbana mjesta, pedesetih godina 20. stoljeća i ranije, u Senj su uglavnom selili mladi radi srednjoškolskog obrazovanja, nakon čega su ondje ostajali živjeti.

Imigranti prolaze cijeli niz procesa prilagodbe u novoj okolini. Koliko će trajati prilagodba, kakav će biti način i stupanj integriranosti u novu okolinu, ovisi o nizu faktora. Miro Prpić Ropeta, Josip Prpić Paljak i Zlatko Tomljanović Pešo kazali su da su nekada postojali veliki antagonizmi između Senjana i stanovnika zaleđa: Ovo su za njih bili sve seljaci, bunjevčenje je za njih bio pojam nečeg lošeg. To je kao čovjek

24 Primjerice, Ivan Vukelić Mikula, Mirko Tomljanović Sova. Više o pčelarstvu vidi u M. Rajković u nastavku ove monografije.

25 Više vidi u: Anđelko Akrap: 'Zapošljavanje u inozemstvu i pripadna depopulacija seoskih naselja', Društvena istraživanja, 72-73, god. 13 (2004), br. 4-5, Zagreb, 675-699; Puljiz V.: 'Ruralno -sociološka istraživanja i glavni trendovi promjena u našem selu', Sociologija sela br.95-97, 1987. ; Ibid.: 'Eksodus poljoprivrednika', Biblioteka sociologija sela, IDIS, Zagreb, 1977. , 173-177.

26 U senjskom kvartu Trbušnjaku žive migranti sa stolačkoga područja. 
nekog drugog reda, sve dok nije počelo naseljavanje, onda se mijenjalo raspoloženje, doduše ima još toga kod nekih ali zapravo tih pravih Senjana nema, to se sve izmiješalo spuštali se Krivopućani, Stolačani, nema više ni $5 \%$ čakavštine u Senju. Stvaranjem simboličnih granica između primorskih Bunjevaca i Senjana bavila se etnologinja Nevena Škrbić Alempijević. U radu navodi kako se pomicanje težišta između regionalnog centra i periferije dade naslutiti u kritičkom promišljanju pojmova "domicilan", "domaći" i "stranac". Sad imamo u Senju tri obitelji koje su još, kako bi vam ja reka, više kao po porijeklu domaće. U gradu nema više Senjana pravoga, to su sve Bunjevci. To su sve ljudi s Krivoga Puta is Vratnika, Senjske Drage iz Like. (2003:442)

Krivi Put je od Senja udaljen svega 14 kilometara, međutim, dnevne migracije nisu bile razvijene. U prvoj polovici 20. stoljeća „mljekarice“ iz Krivoga Puta, ponajviše Alana, Podbila i Primorke svaki bi dan nosile na magarcima mlijeko na prodaju u Senj. ${ }^{27}$ Ostale dnevne migracije bile su individualne i neznatne, upravo zbog nepostojanja javnoga prijevoza do Senja. Nisam zabilježila podatak da je netko iz Krivoga Puta odlazio raditi svaki dan u Senj. Nakon Senja, drugo migratorno područje bila je Rijeka gdje i danas živi mnogo Krivopućana s kojima sam razgovarala. ${ }^{28}$ Odabir Rijeke prvenstveno je počeo odlaskom na srednjoškolsko obrazovanje. Budući da je Rijeka veći grad od Senja, bio je puno veći izbor srednjih škola. Nakon završstka školovanja mladi su ondje ostajali živjeti. U Rijeci, kao ni u Senju, danas nema, niti je ikada bilo, zavičajnih klubova Krivopućana.

\section{RAZLOG DOLASKA KRIVOPUĆANA 5. KOLOVOZA 2004. GODINE U KRIVI PUT}

$\mathrm{N}$ a terensko istraživanje došla sam dva dana prije same proslave blagdana Majke Božje Snježne, odnosno kako je Krivopućani zovu Snježna Gospa. Obišla sam većinu zaselaka u Podbilu, Krivome Putu i dio Mrzloga Dola. Zanimalo me tko je sve došao i kako teku pripreme za proslavu. Raspitivala sam se što mogu očekivati sutra, ne bih li saznala nešto iz osobnih sjećanja Krivopućana. Stanovnici koji stalno borave ovdje užurbano su uređivali domove i okoliš, pripremali hranu za sutrašnje obiteljske goste.

Ivan Tomljanović Čona o prijašnjim je proslavama blagdana kazao: Prije su dolazili iz svakuda, najviše ovi koji su iselili odavle. Onda neko vrijeme nisu smjeli dolazit, u razdoblju socijalističke Jugoslavije, al's ovom novom državom (od osamostaljenja Hrvatske, op.a.) dolazili su svi. Mara Krmpotić Brndina iz Veljuna također se prisjeća razdoblja kada se nije smjelo slaviti te joj je drago što sada dolazi mnogo ljudi: U naše doba se Gospa nije ni smjela slavit, more bit je došlo desetak ljudi, ovih sad zadnjih godina je malo više. A ja znam šezdesete godine nisu smili, bila policija.

Miroslava Filipaš Cotina rođena je u Krivome Putu i udala se u Varaždin prije 45 godina. U Senj dolazi na ljetovanje, te obvezno ode na Snježnu Gospu u Krivi Put: To mi je najbitnije da pogledam, da se sjetim kako sam plesala kolo. Na petunu kolo plesali, kako sam pjevala. Svi smo tamo bili veseli. To nam je sve bilo u životu. Sve je bilo živo, svake nedjelje. Također, tu priliku iskoristi za odlazak u rodno selo Šimeriče i posjet rodnoj kući u kojoj danas živi njezin brat. Kod njega se okupi šira obitelj te nakon mise peku meso na roštilju.

Mnogi stariji sugovornici, na moja pitanja o Majci Božjoj Snježnoj, isticali su baš „kolo na petunu“ kao njima najbitnije mjesto i prvu asocijaciju na proslavu. Osobno, nisam primijetila „petun“ dok nisam za njega upitala i dok mi ga nisu pokazali. Petun je betonirani dio ispred crkve Majke Božje Snježne u Podbilu. Prema Mirijam Kahn, Oznake u okolišu i njihove fizičke oznake (...) za vrijeme svakodnevnog gledanja objekta, onima koji se nalaze izvan te zajednice nemaju smisla kao onima koji tamo žive... Postojeće veze izmedu ljudi i njihove nedavne povijesti, izmedu individua i grupa, izvora njihovog osobnog identiteta, oni su projekcije unutarnjeg emocionalnog krajolika. (...) oni mogu imati smisao za cijelo selo, jednu grupu ili za jednu individuu. Selo ili zajednica su ujedinjeni tim mjestima i onime što ih okružuje, spodsjetnicima koji su povezani s prošlošću is uobičajenim vrijednostima. (2003:194). Upravo se na tom „petunu“ igralo kolo

27 Za detaljnije informacije vidi poglavlje T. Rubić o sajmovima i trgovini u nastavku ove monografije.

28 Anton Špalj Franetov; Jure Tomljanović Ban; Milan Tomljanović Ivić, Podbilo; Vlade Filipović, Krivi Put. 
prije i poslije svake mise, a sam blagdan Majke Božje Snježne bio je povod da ovdje dođe veća skupina ljudi i prilika da se mladi iz udaljenijih mjesta zagledaju i upoznaju.

Večer prije proslave u Krivome Putu bilo je mirno i tiho, tek su pojedini gosti sjedili u gostionici u centru Podbila i pričali. Vatrogasci su vodom oprali cestu, tijekom dana pošišana je trava i žbunje oko ceste, očišćeni su kontejneri za smeće. Mjesto je bilo spremno za sutrašnje posjetitelje. Proslava Majke Božje Snježne uključuje hodočašće i društveno - zabavne elemente. Prostor na kojemu se sve odvija je centar Podbila, obilježen crkvom, gostionicom (sl. 1a, b), grobljem i nogometnim igralištem. Između ovih lokacija od jutra su se smještali trgovci s tri štanda suvenira, pokretni kamioni s hranom i pićem, na dva su mjesta improvizirani stolovi na kojima se prodavala janjetina; svi su prilazi bili popunjeni osobnim automobilima te jednim autobusom koji je došao iz Senja. Dolazili su posjetitelji, hodočasnici, iseljeni Krivopućani i njihovi gosti. Prostor koji je prilikom svih mojih dotadašnjih boravaka bio pust dobio je novu sliku, veselu i dinamičnu; ljudi su se susretali s rodbinom i poznanicima (sl. 1b).

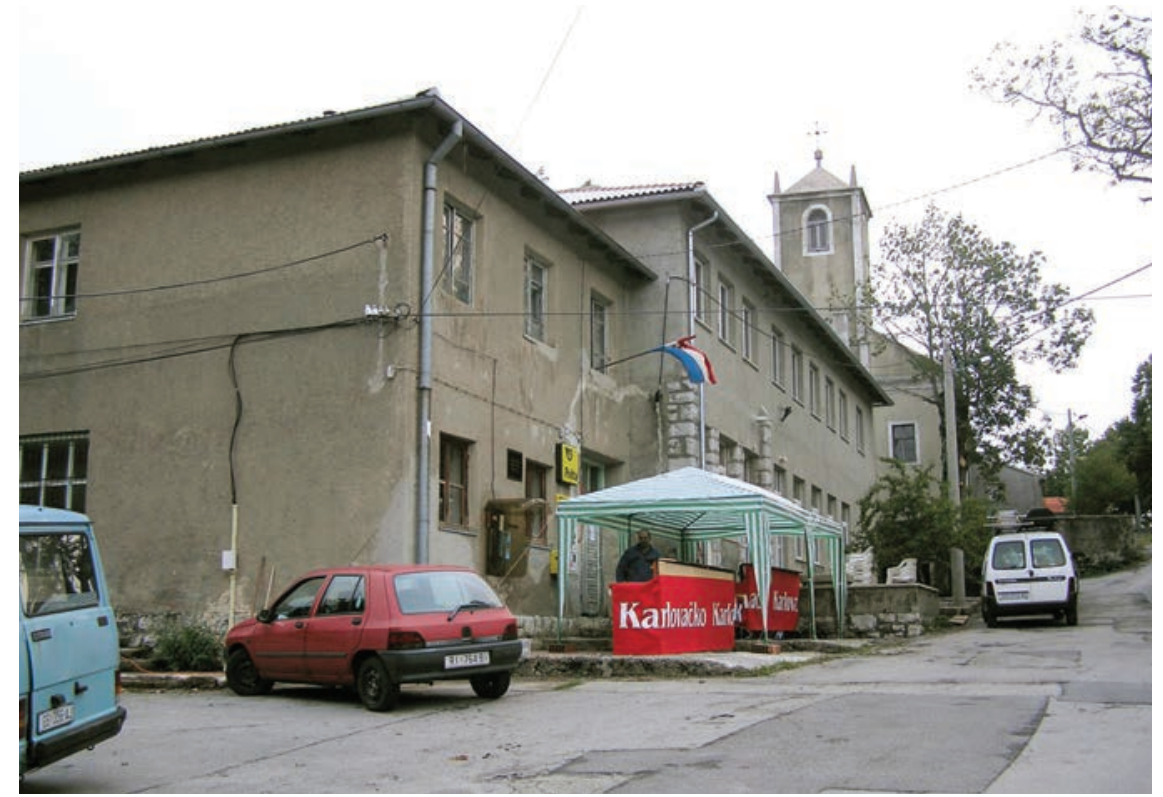

Slika 1a: Centar Podbila, pogled na poštu, društveni dom i crkvu; snimila M. Rajković 5. kolovoza 2004.

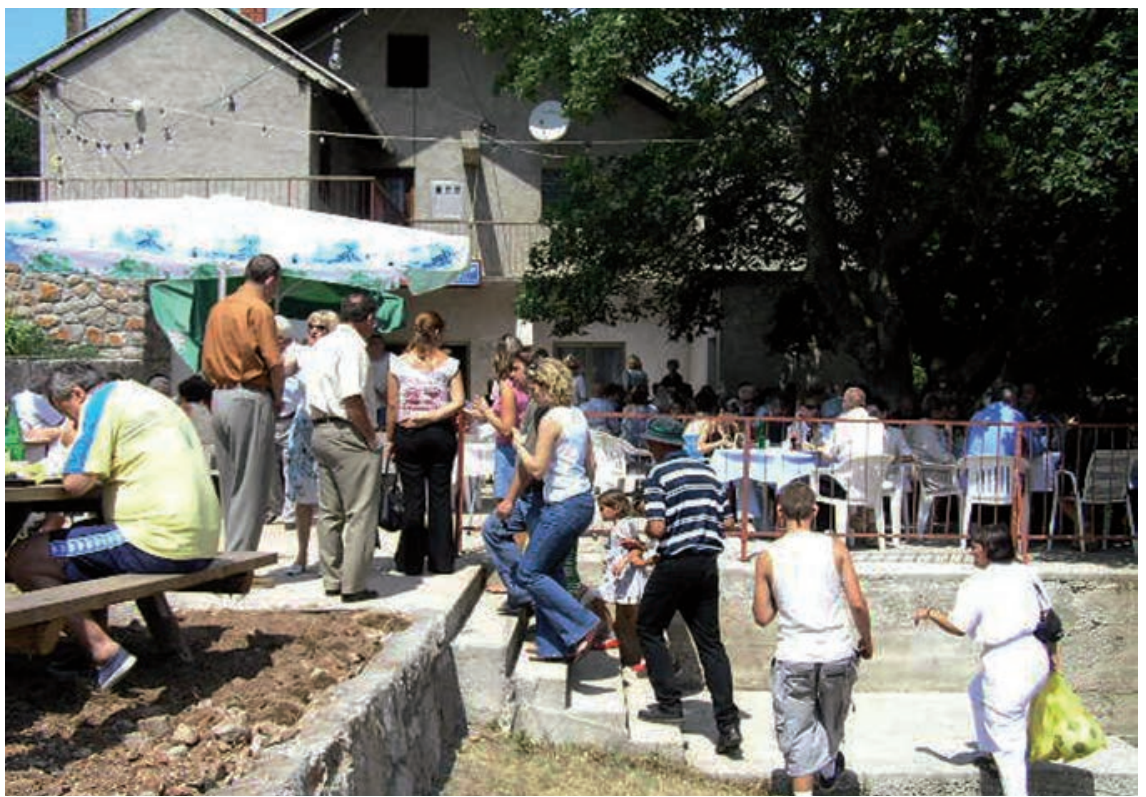

Slika 1b: Centar Podbila i gostionica "Luka" vlasnika Petra Tomljanovića Čone; snimila M. Rajković 5. kolovoz̧a 2004. 
Prilikom dolaska, gotovo su svi obišli grobove, a mnogi su dan ranije donijeli svijeće i cvijeće (sl. 2). Naime, i nakon trajnih iseljavanja mnogi se Krivopućani sahranjuju na groblju u Podbilu, posebice oni koji žive u Senju. No, ako je osoba iz Krivoga Puta odselila u Senj i ondje se sahranjuje, gotovo svi Krivopućani, bilo da žive u Senju ili Krivome Putu, nastoje doći na sahranu. Tako se primjerice zatvara trgovina u Krivome Putu jer trgovkinja ide na sahranu, neovisno o radnome vremenu. Pojedini potomci migranata iz zapadne Europe dopremaju posmrtne ostatke svojih bližnjih i po njihovim ih željama sahranjuju u Podbilu. ${ }^{29}$ Međutim, kazivači ističu da je takvih slučajeva sve manje jer djeca žele da roditelji budu pokopani u mjestu gdje oni žive ne bi li im bili bliže za odlazak na grob.

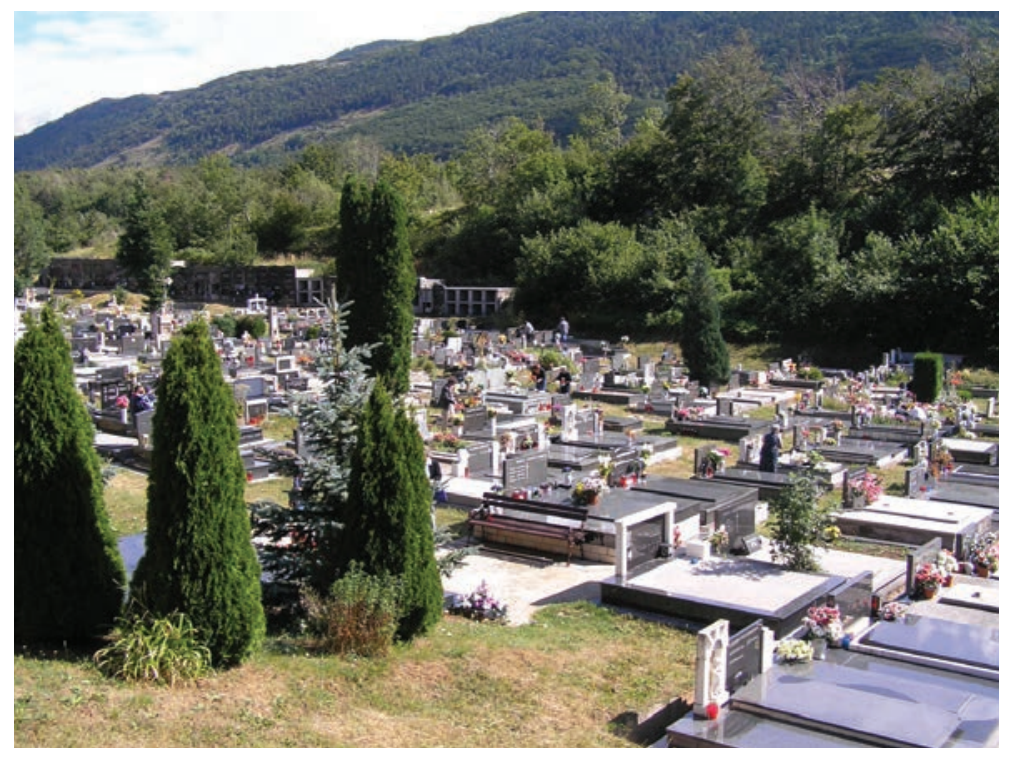

Slika 2: Groblje u Podbilu; snimila M. Rajković 5. kolovoza 2004.

Jedni su odlazili na misu, drugi u gostionicu, a treći su razgledavali štandove sa suvenirima ili pričali s poznanicima. Sam događaj pratili smo kroz dvije žarišne točke, crkvu i gostionicu. M. Kulišić i I. Vuković bile su u crkvi na misi, a ja sam ispitivala kazivače u gostionici i okolnom prostoru. Za vrijeme prve mise u gostionici sjedila je uglavnom muška populacija. Anton Špalj Franetov iz Podbila, koji danas živi u Rijeci, svoje je prisustvo ovdje ocrtao riječima: Nisam bio dugo na Gospi, otkada sam nastradao (imao amputaciju potkoljenice op. a.), sad sam došao. Imam tu i rodbine, malo sinovci, od bratića kćer, u Cupićima. Tu sam došao sa ženom, ona je u crkvi, a ja sam ovdje u kapelici kod Čone (smijeh) (Čona je nadimak vlasnika gostionice, op. a). Svoju je ulogu u gostionici šezdesetogodišnji muškarac objasnio: Žena je otišla u crikvu, a ja ovde čuvam mjesto da možemo poslije jest janjetinu. Kako sam dobar muž, jelte?

Za susjednim stolom sjedila su četiri muškarca: Mi smo svi rodbinski vezani ovdje, ja imam punicu $i$ zbog janjetine smo došli (smijeh). Jer sad se vidimo s puno ljudi koje inače ne vidimo svake godine dođem na Gospu. A s familijama smo došli, samo ženski rod je u crikvi a mi tu u našoj drugoj crikvi, drugom popu se molimo (smijeh). Stipe Prpić Stipina iz Gorice s prijateljima iz Longovca stajao je preko puta crkve. Primarni razlog njihova boravka ovdje bio je da se sretnu s ljudima: Ja se doma molim Bogu, svaku veće, ne moram ić" u crkvu mogu se molit $i$ iza kuće, ja idem Čoni. Čona ima najbolju kapelicu, pivicu i gemišt, rekao je isti kazivač. Mnogi ljudi samo su sjedili na niskoj ogradi oko crkve ili na prostoru između crkve i gostionice (sl. 3). Promatrali su posjetitelje i razgovarali. Neki su čitav dan proveli u centru Podbila.

29 Stipe Prpić Stipina, Petar Tomljanović Čona, Mara Krmpotić Brndina. 


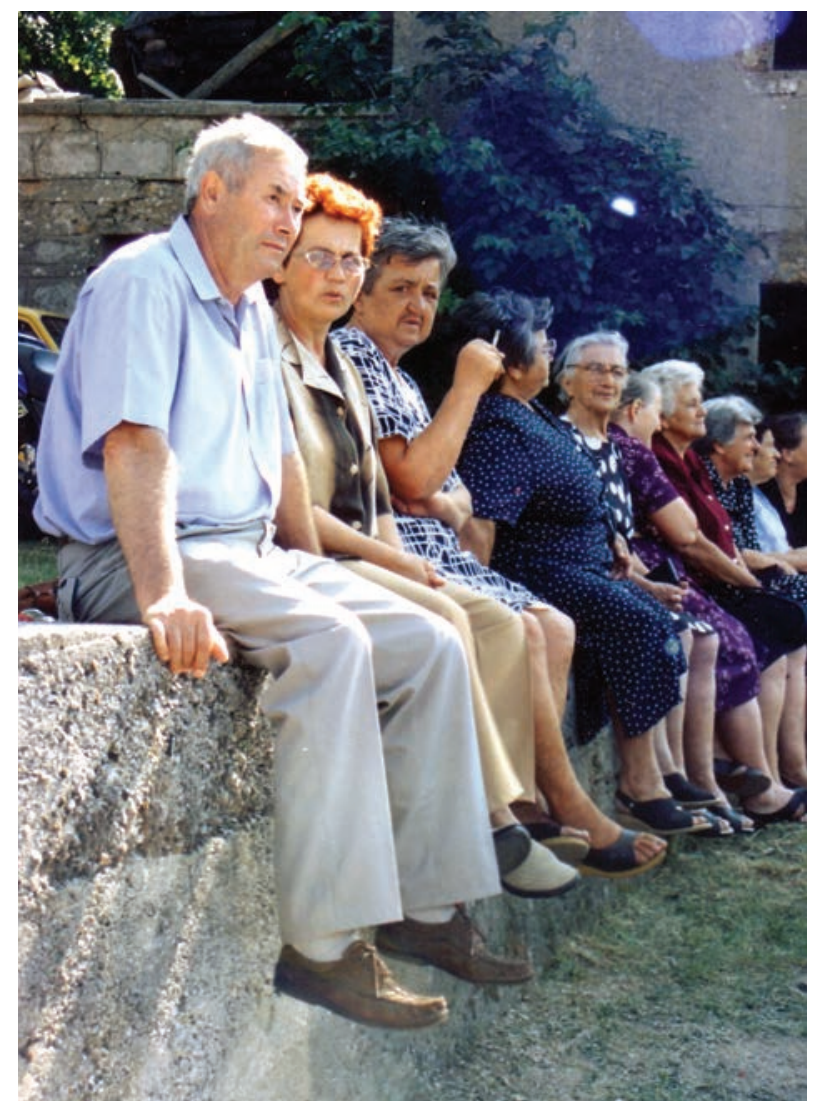

Slika 3: Skupina ljudi sjedi u centu Podbila; snimila Marija Kulišic 5. kolovoza 2004.

Skupinu mladih (rođeni od 1987. do 1982./83.) srela sam kako sjede postrani između crkve i gostionice. Došli su pješice iz Senja jer imaju ovdje baku i djeda, a glavni je cilj bila „roštiljada“ u Matićima. Najvažniji razlog boravka pojedinih kazivača 5. kolovoza u Krivome Putu bio je upravo nogometni turnir koji organizira NK „Bunjevac“ unazad deset godina (sl. 4).

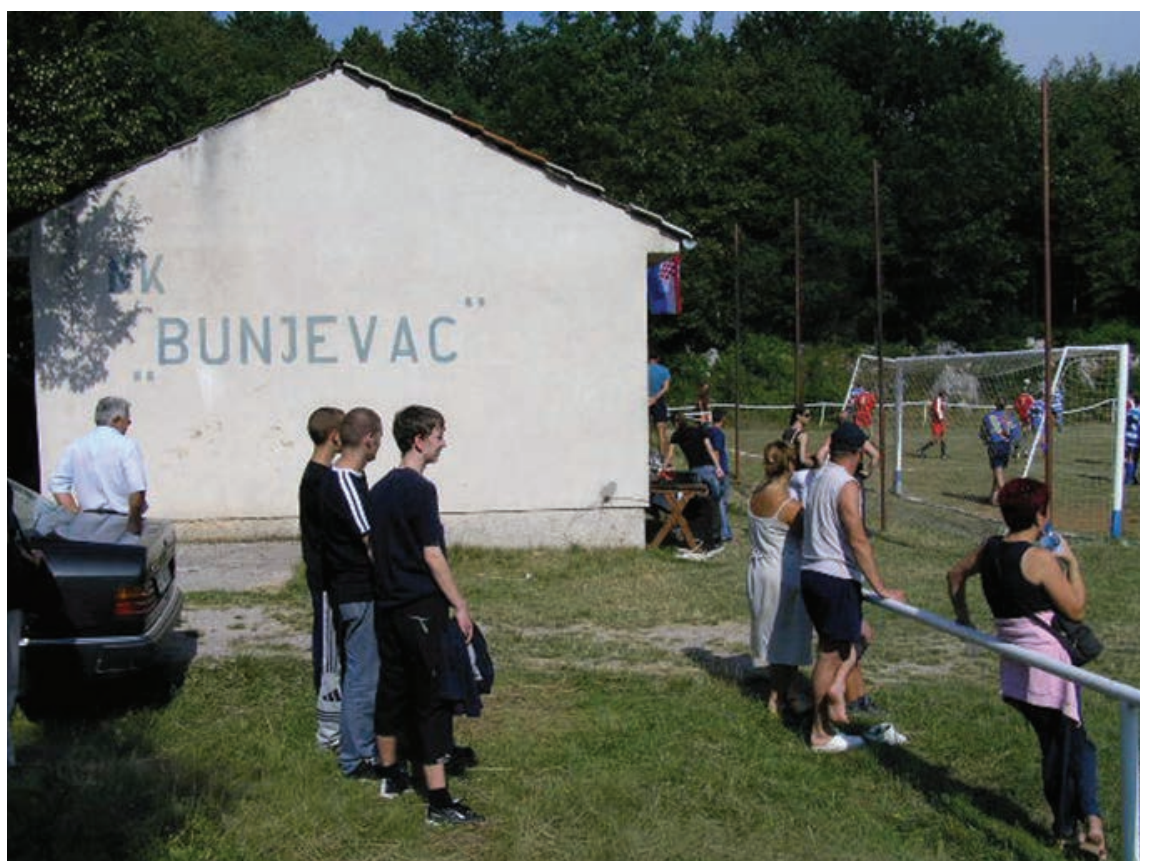

Slike 4: Prostorije NK "Bunjevac” i dio nogometnog igralista; snimila M. Rajković 5. kolovoza 2004. 
$\mathrm{Na}$ proslavi su bili i vatrogasci koji su dežurali s vodom. No, ovdje nisu bili isključivo službeno, došli su s obitelji i djecom: I prošlih godina smo bili ovdje, ja sam došao s djecom i baba je sad u crkvi. Inače živim u Senju, a rodom sam iz Klaričevca. Ovakvih je priča bilo mnogo. Ivan Tomljanović Čona iz Podbila smatra da ljudi ovdje dolaze na ljetovanje, na godišnji odmor, onda za usput dođu na Snježnu Gospu i sastanu se s familijom. To je sve jedno s drugim povezano.

Proslavi Majke Božje Snježne nazočila sam i 2005. godine kada su na njoj prisustvovali Bunjevci iz Bačke (sl. 5). Ideja je krenula na poticaj pojedinaca, pri čemu su pomogle lokalne političke elite i svećenstvo. Naime, Hrvatska udruga kulture "Lajčo Budanović", Mala Bosna, iz Subotice gostovala je u Senju i Krivome Putu. ${ }^{30}$ Stipan Dulić, tajnik društva, rekao je o inicijativi: Rođen sam u Maloj Bosni, 1994. kad je rat bio ... nama je ponudena zamjena, pa sam ja zamijenio stambeni objekt u Subotici za Senj i boravim ponekad u Senju. Dogovarao sam sa svećenikom da dodemo ovdje... da se uspostavi suradnja ovih primorskih s bačkim Bunjevcima. O važnosti gostovanja za bačke Bunjevce isti je kazivač dodao: Put je financirala Republika Hrvatska, preko konzulata najveći dio, jače od polovine ... ja bi volio kad bi se to svake godine održavalo, a ujedno bi želio ugošćavati i ovdašnje Bunjevce, ja bi volio... da pokažemo ondašnjim Bunjevcima hrvatsku kulturu ovih Bunjevaca. A nama je značajno našoj dici pokazati Hrvatsku da bi se to održalo, onda di ćeš ih odvesti, svi žele ić na more. Vam to nije ništa al nam je, to je za njih taki doživljaj da je to neopisivo, evo loše je vrime al to nije važno, oni su se kupali. Vecina od njih je prvi put u Hrvatskoj.

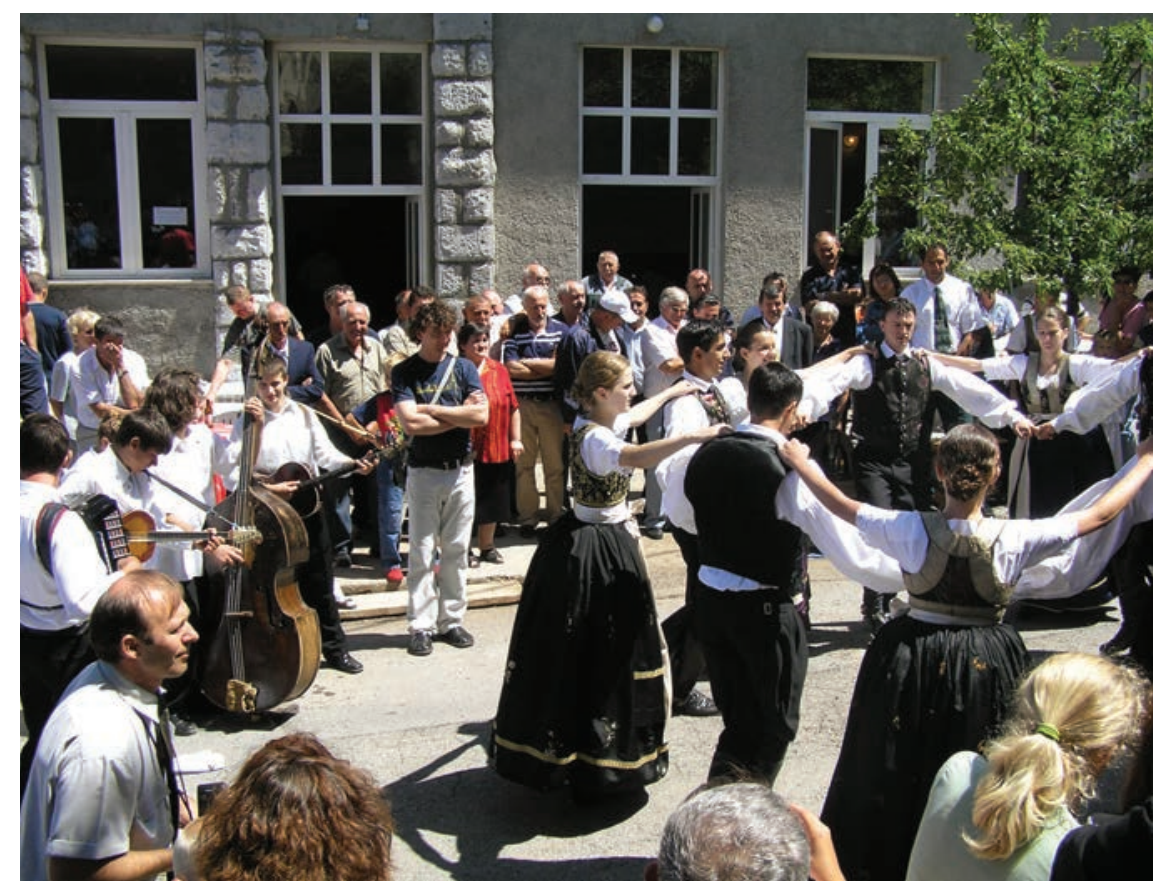

Slika 5: Nastup članova HUK u Podbilu "na petunu”; snimila M. Rajković. 5. kolovoza 2005.

Godine 2005. novitet je bila prodaja i prezentacija izrade dva oblika novčića s motivom crkve Majke Božje Snježne i Krivoga Puta, te šahovnice i natpisa „Bunjevac u srcu“ (sl. 6).

30 Doputovali su u petak 4. kolovoza i otputovali 8. kolovoza. Bili su smješteni kod ljudi u Senju i kod svećenika Mile Čančara. Folklorna sekcija nastupila je u Krivome Putu i Senju, prisustvovali su svetoj misi u Senju, obišli Gradski muzej i tvrđavu Nehaj. 


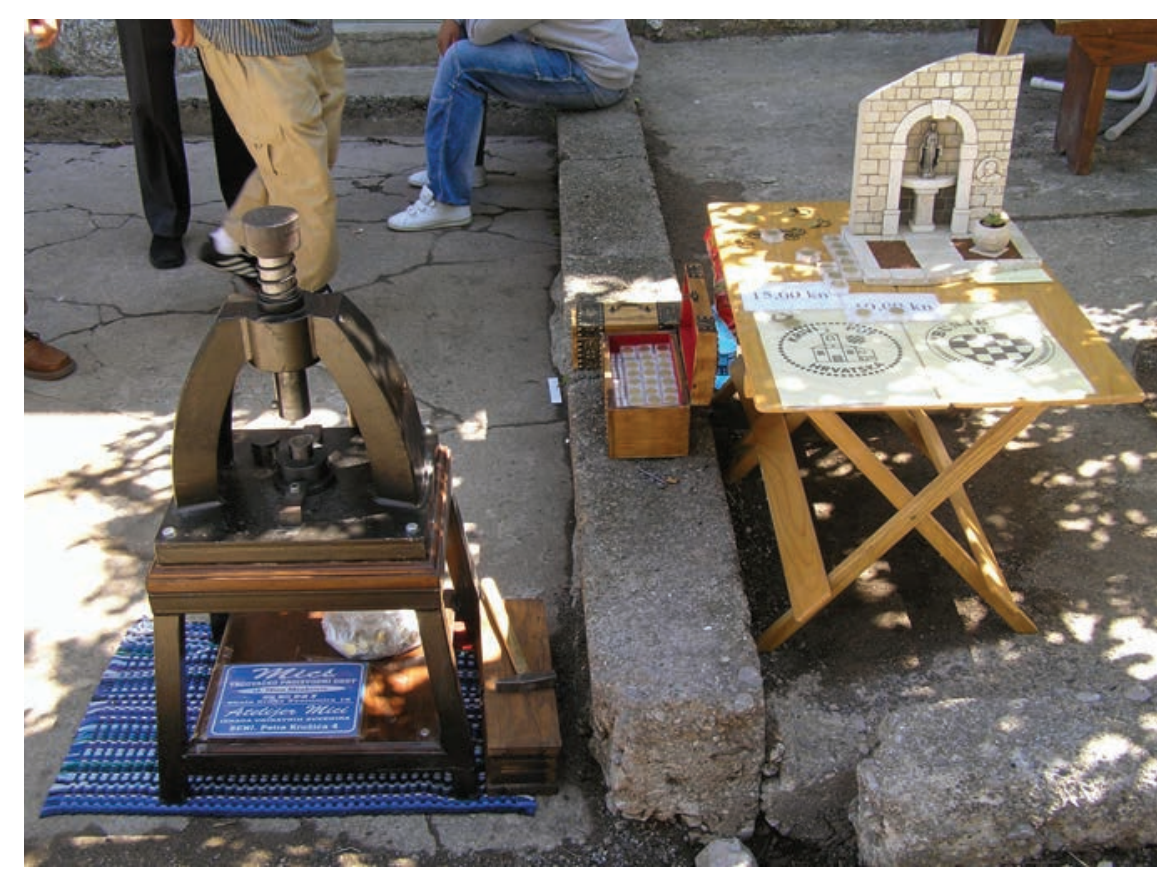

Slika 6: Štand za iąradu i prodaju novčica s motivom crkve Majke bǒ̌je Snję̌ne i Krivoga Puta, te šahovnice i natpisa „Bunjevac u srcu“; snimila M. Rajkovic 5. kolovoza 2005.

\subsection{POVRATAK U LOKALNU ZAJEDNICU}

$\mathrm{M}$ noge su se privremene transkontinentalne migracije pretvorile $\mathrm{u}$ trajne. Potomci tih migranata $\mathrm{i}$ danas posjećuju Krivi Put, posebice na proslavu Majke Božje Snježne, što se vidi u kazivanju Miroslave Filipaš Cotine: Na Gospu i iz Australije znaju doć. Čita svećenik na misi 'ko je sve došo, ko je dao novac (smijeh). Prije dvi godine sam vidla školskog kolegu. Bilo mi je strašno drago, godine su to, i on se opet vratio natrag u Australiju. Došo je majku pogledat bila je na umoru i na Gospu, i opet se vratio jer tamo su mu sva braća u Australiji. Išo je najstariji pa je povukao ova dva, to su ovi Markisini, jedan brat im je u Zagrebu. Navedeni je primjer ujedno potvrda lančane migracije.

Dolasci iseljenih Krivopućana, kao i njihovih potomaka, ostaju zabilježeni u sjećanju zajednice. Primjer za to je nedavni posjet potomaka obitelji Prpić iz Amerike: Sad je baš nedavno bilo dva puta sastala se čitava familija iz Amerike, Prpići neki. Kažu da danas imaju dvjesto pedeset potomaka, a ovdje ih je došlo pedeset. ${ }^{31}$ Stalni stanovnik iz Podbila Ivan Tomljanović Čna kazao je: A ima ih dosta koji dolaze izvana, neki su došli danas, jedan gospodin koji živi u Americi, ima brata koji živi u Novom Vinodolskom, i baš su danas bili tu. On dolazi skoro svake godine, za sad dok je za ove nove države, prije se nije smilo. Budući da u ovom kraju svi imaju nadimke, iseljenici ih katkada dobivaju prema mjestu iseljenja, primjerice Ontario, Kanada.

Ranije je spomenuto da mnogi iseljeni Krivopućani provode ljeta u Krivome Putu. Ivan Tomljanović Čona rekao je da se ljudi vraćaju u zadnje vrijeme: Ali slabo, to se već izrodilo, to ni ne zna više hrvatski jezik. Najviše Australija, Kanada. Jedan se vratia sam, žena još radi, djeca su već Kanadani i to je to. A neki su obnovili tu kuće. Jedan od povratnika s kojim sam razgovarala bio je Ivan Tomljanović Rokin. On se vratio živjeti u Vratarušu prije sedam godina gdje danas živi sam. Svoj današnji život ocrtao je riječima: Sam sam, imo sam koze, pa sam proda, pa svinje. Onda sam sadio mrkvu pa ju pojede medvid, jelen raskopa krumpir a srna cikle, nema tu to je sve politički nastrojeno (smijeh), a kiše nema za ništa, odma te uništi. A

31 Josip Prpić Paljak; Zlatko Tomljanović Pešo. 
imam kuću veliku u Gorskom kotaru 460 kvadrata, tamo mi je sin i nevista i dvoje djece, a najljep̌se ovde sam, de sam se rodio.

Poneki s kojima sam razgovarala planiraju se vratiti. Primjer za to je kazivanje pedesetogodišnje žene na privremenom radu u Njemačkoj: Moj stariji brat iz Njemačke se planira vratit, tu je napravio kuću. A ovaj iz Kanade isto kaže da će se vratit, dolazi unazad pet godina sobitelji, isto je napravio kuću ovdje. Mi smo isto napravili kuću. Moj muž još nije u pravoj penziji, ali kad bude možda ćemo se vratiti. A čujte ovdje nije loše ljeti, po danu možete ići na more na kupanje, a ovdje gore se fino spava. Dok tek pojedinci imaju takve planove, obnavljaju ili grade nove kuće u Krivome Putu, većina ih kupuje nekretnine na atraktivnijim lokacijama uz obalu. Petar Tomljanović Čona kazao je: Došo je jedan Amerikanac, iz Njemačke puno, svake godine, neki imaju kuće u Senju ili po obali. Jedan je došao prije dva mjeseca kupio je stan u Novom Vinodolskom i tu će ostati živjeti. Miro Prpić Ropeta dodao je: Malo tko se vraća živjeti ovdje, uglavnom naprave kuće u Senju ovdje je starina, malo tko.

Tijekom razgovora mnogi su migranti isticali "velike" kuće, školovanje djece, društveni i imovinski uspjeh, kako njih samih, tako i bliže obitelji. Jedan od brojnih primjera naveo je Ivan Tomljanović Rokin: Brat je u mirovini, ali živi u Francuskoj. Također je napravio veliku kuću u Senju, dođu nekad za godišnji, a imaju isto veliku kuću u Francuskoj. Sinovi su na velikom položaju, jedan je direktor tvornice a drugi aerodroma. Naime, kada migrant promjeni svoju kulturnu sredinu, on često mijenja i svoj socijalni položaj. Svaki socijalni položaj ima dvije dimenzije. Jedna je statusna, naime znamo da imigranti općenito imaju niži socijalni status u zemlji imigracije koji onda pokušavaju kompenzirati "višim" statusom u svojoj socijalnoj okolini iz koje su emigrirali. (Živković et al., 1995:12). Gotovo svi s kojima sam razgovarala imaju nekretnine na obali u kojima borave tijekom godišnjih odmora ili tek nekoliko dana godišnje.

Osim stalnih i povremenih boravaka u Krivome Putu, vrlo su česti i dnevni boravci. Naime, dolazeći u Krivi Put često sam susretala iseljene Krivopućane kako roditeljima cijepaju drva, pomažu prilikom obavljanja kućanskih poslova ili pak u svojim vrtovima sade povrće, obrezuju voćke, odmaraju. Ti boravci ovise o slobodnom vremenu pojedinca, bilo radnim danom ili vikendom.

\section{ZAKLJUČAK}

$\mathrm{O}$ vaj je rad imao dva cilja. Prvi je prikazati migracije Krivopućana tijekom 20. stoljeća, a drugi saznati njihovu današnju povezanost s lokalnom zajednicom. Kazivanja o migracijama stanovništva odnosila su se na 20. stoljeće, za razliku od onih koja su se odnosila na dolazak iseljenih Krivopućana na proslavu Majke Božje Snježne gdje je naglasak stavljen na 2004. godinu.

Migracije Krivopućana bile su vanjske i unutarnje. Vanjske su migracije one pri kojima pojedinci i skupine odlaze u neki drugi, bitno različiti kulturno-politički prostor. (Ibid. 10) Vanjske migracije Krivopućana bile su transkontinentalne migracije u Ameriku, Australiju i Kanadu, migracije u zapadnu Europu (ponajviše Njemačku, Francusku, Švicarsku) te migracije u susjedne zemlje (države bivše Jugoslavije, primjerice Srbiju, Crnu Goru, Sloveniju, Bosnu). Unutarnje migracije su one pri kojima pojedinci ostaju u sklopu istog socio-kulturnog-političkog prostora, ali se geografski kreću. (Ibid.) Unutarnje migracije bile su masovnije u Slavoniju, pojedinačne u druge dijelove Hrvatske te migracije u bliža urbana središta, Senj i Rijeku. No, podjelu na vanjske i unutarnje migracije treba razmotriti iz perspektive tadašnjih migranata. Današnje "vanjske" migracije, termin teoretičara migracija, ne odgovara svijesti tadašnjih migranata. Naime, prema njihovim tumačenjima, njima je bilo svejedno hoće li otići u Slavoniju, Vojvodinu, Srbiju ili Rumunjsku, bilo je bitno da ima šuma. Osim toga, za ta im područja nisu trebali jamstveni dokumenti kao za zapadnu Europu. U najvećem broju slučajeva, prilikom odlaska, nisu imali točno odredište kamo idu, već su migracije bile lutajuće.

Migracije Krivopućana mogu se podijeliti u nekoliko faza prema zemljopisnoj udaljenosti odlazaka. Faze uglavnom postoje i paralelno, nisu ni isključive ni kronološke, premda se opažaju promjene u tendencijama. Te faze ujedno odgovaraju migracijskim trendovima s područja cijele Hrvatske. Stoga sam 
migracije Krivopućana nastojala ocrtati u kontekstu migracija cjelokupnoga hrvatskog stanovništva, tamo gdje je to bilo moguće.

Migracije su prema duljini trajanja bile trajne, privremene i sezonske. Također su bile individualne, lančane i lutajuće. Pojedine privremene migracije, koje su najčešće bile lutajuće, pretvorile su se u višegodišnje kroz čitavi radni vijek, ali i postajale trajnima, posebice ako su bile lančane. Odvijale su se u mirnodopskim uvjetima i bile su dobrovoljne. Geografska udaljenost odlaska od domicilnog prostora određivala je kontinuitet i intenzitet veza sa srodnicima, prijateljima i cijelim socijalnim i kulturnim sustavom iz kojega su migranti došli. Nastojala sam saznati čimbenike potiskivanja i privlačenja ("push” i "pull” faktore). Najveći potisni čimbenici ujedno su i bili i najveći privlačni: bolje ekonomske mogućnosti u drugoj sredini, stjecanje bolje naobrazbe i bolji uvjeti rada, bolji životni uvjeti, odlazak za nekim tko na bilo koji način privlači aktera migracija, što dovodi do stvaranja mreža i migracijskih valova. Zabilježila sam nekoliko političkih razloga migriranja, no nisam uspjela razgovarati ni s jednim političkim migrantom. Glavni razlog raseljavanja Krivopućana bila je ekonomska stagnacija poljoprivrede, urbanizacija, nepostojanje infrastrukture i komunikacije $s$ bližim urbanim centrima.

U radu sam nastojala prikazati privremena vraćanja u lokalnu zajednicu ili stalne povratke, odnosno današnji odnos migranata i njihovih potomaka prema Krivome Putu. Iseljeni se Krivopućani tek u neznatnom broju vraćaju živjeti u Krivi Put, odnosno najviše ondje borave ljeti. Ove bismo ljetne boravke mogli shvatiti kao specifične migracije čiji se broj povećava unazad desetak godina. Do sedamdesetih godina 20. stoljeća na tim se područjima odvijalo etapno seljenje zbog ispaše stoke. Od sedamdesetih godina sele pojedinačno umirovljenici i borave na Krivome Putu od svibnja do listopada, odnosno do prvog snijega. Posjećuju ih djeca i unuci vikendima i tijekom godišnjih odmora.

Veliki dio Krivopućana koji danas ne živi u Hrvatskoj gradi kuće na obalama većih urbano-turističkih centara poput Senja, Crikvenice ili Novog Vinodolskog. No, na proslavi krivoputskoga blagdana Majke Božje Snježne, svi nastoje biti tamo. Smatram da je dosta ljudi 5. kolovoza 2004. godine boravilo u Krivome Putu zbog vjere ili barem zbog Majke Božje Snježne. Iskazi o Majci Božjoj Snježnoj u Krivome Putu veoma su važni stoga što ukazuju kako je Majka Božja Snježna pojavom i značenjem integrirana u lokalnu zajednicu. Vjerovanje u Majku Božju Snježnu može se shvatiti kao dio identiteta zajednice. O važnosti Majke Božje Snježne u oblikovanju identiteta zajednice najbolje svjedoče kazivanja u kojima se ona spominje u inačicama poput: „Zaštitnica našeg mjesta“ ${ }^{2}$, „naša svetica“33, „naša zaštitnica“34 ili pak kao „lokalna zaštitnica“. ${ }^{35}$ (Kulišić i Vuković 2004:244) Naime, Majka Božja Snježna pojavom je i značenjem integrirana u lokalnu zajednicu i stoga se vjerovanje u nju može shvatiti ne samo kao dio osobnoga identiteta, nego kao i jedan od glavnih markera u očuvanju identiteta ove raseljene zajednice. Prema jednom kazivaču, Majka Božja Snježna ima važnu ulogu i u povijesti zajednice krivoputskih Bunjevaca jer, kako je naveo, lik Majke Božje Snježne su Bunjevci kao svoju zaštitnicu nosili u seobi sa sobom i donijeli je u Krivi Put. (Ibid. ) Identitet je, kao posljedica čina poistovjećivanja, skup odlika (ili čak temeljna crta) koje određuju subjektivnu pripadnost skupu uvjerenja, činjenja (ili ljudi) kojima (i kojima se) pojedinca povezuje sodredenom sredinom, ljudima, stvarima i dogadajima i na taj način ga obilježuju. Osobnost i pripadnost temeljne su odrednice identiteta a obje su proizvod procesa poistovjećivanja. (Zorić prema Grbić 1994:23) Za koncept identiteta bitna je pretpostavljena svijest o poistovjećivanju s kolektivitetom (identifikaciji), čime se težište postavlja na subjektivne aspekte društvenog odnosa. (Banovac 1998:17) Iako je mjesto u prošlosti u antropološkoj literaturi dugo bilo potisnuto, nedavno su na njega više obratili pažnju. (Kahn 2003:193) Pitanje prostorne identifikacije treba se razmotriti u kontekstu širih društvenih procesa. Ako se prisjetimo kazivanja da se do devedesetih godina 20. stoljeća blagdan Majke Božje Snježne obilježavao jako slabo i da je dolazila tek nekolicina ljudi, moramo ovu proslavu, kao i identitet raseljene zajednice, promatrati u društveno-političkom kontekstu.

32 Marija Tomljanović, Krivi Put.

33 Ana Šojat i Ante Šojat Tine, Šojatski Dolac.

34 Jure Tomljanović, Podbilo.

35 Milan Prpić i Milka Prpić, Veljun. 
Naime, nakon 1995. godine, 5. kolovoza je državni praznik obilježavanja vojne akcije Oluja, nakon čega su se u Krivom Putu počeli održavati i nogometni turniri. Značaj lokalnoga identiteta potaknuo je religijski osjećaj, slobodan dan zbog političkog blagdana, vjerski i športski događaj unazad desetak godina.

\section{LITERATURA}

BABIĆ, Dragutin, MESIĆ, Milan (2003): Međunarodne migracije; tokovi i teorije. Prikazi i recenzije. Migracijske i etničke teme, god. 19, br. 1:119-122.

BANOVAC, Boris (1998): Drustvena pripadnost, identitet, teritorij. Rijeka.

BANOVAC, Boris (2004): (Re)konstrukcija socijalnog prostora periferije, prilog istraživanju kolektivnih identiteta u hrvatskoj periferiji. Revija za sociologiju 3-4: 95-112, Zagreb.

BANOVAC, Boris; BLAŽEVIĆ, Robert; BONETA, Željko (2004): Modernizacija (i/ili europeizacija) hrvatske periferije-primjeri Istre, Like i Gorskog Kotara. Revija za sociologiju 3-4:112- 141, Zagreb.

CONNERTON, Paul (2004): Kako se društva sjećaju. Antibarbarus, Zagreb.

ČERNELIĆ, Milana (2000): Dvije zadružne obitelji na području Krivoga Puta. Senjski zbornik 27:199216, Senj.

FRIGANOVIĆ, Mladen (1975): Socijalni aspekti demografskih kretanja u SR Hrvatskoj. Revija za sociologiju, 1-2:32- 50, Zagreb.

GRBIĆ, Jadranka (1994): Identitet, jezik i razvoj. Institut za etnologiju i folkloristiku, Zagreb, 20-47.

FASSMANN, Heinz; MÜNZ, Rainer (1995): Migracije istok-zapad u Europi od 1918. - 1992. Migracijske teme vol.11., br.1:53-87.

HERŠAK, Emil (ur.) (1998): Leksikon migracijskog i etničkog nazivlja. Institut za migracije i narodnosti, Školska knjiga, Zagreb.

HOLJEVAC, Većeslav (1967): Hrvati izvan domovine. Matica Hrvatska, Zagreb.

KAHN, Miriam (2003): Your Place and Mine: Sharing Emotional Landscapes in Wamira, Papua New Ginea. U (ur. Steven Feld \& Keith H. Basso): Senses of Place, School of American Researced Advanced Seminar Series, 167-196.

KULIŠIĆ, Marija; VUKOVIĆ, Ivana (2004): Majka Božja Snježna u pučkoj pobožnosti na području Krivoga Puta. Senjski zbornik 31: 239-260, Senj.

KORENČIĆ, Mirko (1979): Naselja i stanovništvo SR Hrvatske 1857-1971. Zagreb, 603-607.

MESIĆ, Milan (2002): Medunarodne migracije tokovi i teorije. Societas, Zavod za sociologiju, Zagreb.

MIKAČIĆ, Vesna (1990): Vanjska migracija. U: Demografski faktori razvoja Hrvatske, Institut za društvena istraživanja Sveučilišta u Zagrebu, Zagreb, 119-141.

NEJAŠMIĆ, Ivica (1989): Bibliografija radova o unutrašnjoj migraciji stanovništva Jugoslavije u poslijeratnom razdoblju (1945-1986). Institut za migracije i narodnosti Sveučilišta u Zagrebu, Zagreb.

PAVELIĆ, Milan (1979): Partizanski odred Alan. Senjski zbornik 7:211-220, Senj.

RUBIĆ, Tihana (2004): Sajmovi i trgovina, rezultati istraživanja na podrućju općine Krivi Put. Senjski zbornik 31:287-324, Senj

SABLJAK, Tomislav (2001): Rječnik hrvatskog žargona. Biblioteka Lexica, Zagreb.

ŠKRBIĆ ALEMPIJEVIĆ, Nevena (2003): Prilozi poznavanju primorsko-bunjevačkog identiteta. Senjski zbornik 30:425-444. Senj.

ŠTAMBUK, Maja (1981): O pokretljivosti seoskog stanovništva. Revija za sociologiju, vol, XI (1981), No. 3-4:125-130.

TARI, Dragutin (1986): Prilozi za poznavanje razvoja drvne industrije u Virovitici. Virovitički zbornik 1234-1984., Virovitica, 581-590.

UROIĆ, Marija; HURM, Antun (1994): Njemačko-hrvatski rječnik s gramatičkim podacima i frazeologijom, 2. izdanje. Školska knjiga, Zagreb.

ŽIVKOVIĆ, Ilija; ŠPORER, Željka; SEKULIĆ, Duško (1995): Asimilacija i identitet. Školska knjiga, Zagreb. 